\title{
An investigation of the debris-rich basal ice from Worthington Glacier, Alaska, U.S.A.
}

\author{
Jane K. Hart, ${ }^{1}$ Richard I. WalleR ${ }^{2}$ \\ ${ }^{1}$ Department of Geography, University of Southampton, Southampton SO17 1BJ, England \\ ${ }^{2}$ School of Earth and Environmenlal Sciences, University of Greenwich, Medway Campus, Chatham Maritime ME4 4TB, England
}

\begin{abstract}
This paper examines the debris-rich basal ice layer from Worthington Glacier, Alaska, U.S.A., a small valley glacier overlying rigid bedrock. The debris-rich basal ice layer studied shows evidence for large-scale longitudinal compressive deformation (isoclinal folds and nappes), similar in style and magnitude features to that reported from push moraines formed in glacial sediments. The debris-rich ice largely comprised stratified solid ice (layers of alternating debris-rich and debris-poor ice) which we suggest results from the tectonic attenuation of folds produced from the deformation of the frozen debris, glacier ice and bubble-rich ice that comprise the initial basal layer of Worthington Glacier. Beneath the glacier lies a thin bed of saturated diamicton which contains evidence of limited movement. It is suggested that this is the result of the partial melt-out of the debris-rich basal ice layer which then behaved as a local (and seasonal) thin deforming layer.

It is suggested that this example, from a valley glacier flowing over rigid bedrock, provides further evidence that the processes of sediment transport, incorporation and deposition in the debris-rich basal ice are similar to and linked with those in the deforming layer.
\end{abstract}

\section{INTRODUCTION}

It has been suggested by a number of researchers that sediment at the base of a glacier, either in the deforming layer (Boulton and Jones, 1979; Alley and others, 1986; Boulton and Hindmarsh, 1987) or in the debris-rich basal ice layer (Echelmeyer and Zhongxiang, 1987; Brugman and Iken, 1988), can largely account for ice movement. In addition, Hart (1995a) has suggested that there is a deforming-bed/ debris-rich-basal-ice continuum whereby similar processes occur throughout the two different subglacial environments. These include: (1) similar longitudinal deformation patterns, i.e. longitudinal compression at the margin, longitudinal extension and simple shear up-glacier (with the attenuation of stratified solid sub-facies ice into stratified discontinuous and stratified suspended sub-facies; terminology after Lawson, 1979); and (2) similar and interrelated sediment incorporation processes. It was also suggested by Hart (1995a) that the major differences between the deforming layer and the debris-rich basal ice layer are that the processes occur at a much faster rate within the deforming layer, and that probably preservation in the geological record will be restricted to the deforming layer.

In the study by Hart (1995a), three glaciers with different subglacial environments were studied. In contrast, both a debris-rich basal ice layer, and a saturated subglacial layer were present at Worthington Glacier, Alaska, U.S.A., enabling the authors to investigate the interaction between the two layers.

\section{WORTHINGTON GLACIER}

Worthington Glacier is a small valley glacier (approx. $10 \mathrm{~km}^{2}$; Ferguson, 1992) which flows down from a height of
$2077 \mathrm{~m}$ to $612 \mathrm{~m}$ a.s.l. from the western Chugach Mountains in south-central Alaska, $48 \mathrm{~km}$ northeast of Valdez (Fig. la and b). The bedrock is the Upper Mesozoic, Valdez Group of the Chugach Terrane, which comprises metamorphosed marine sediments (siltstones, sandstones and conglomerates) (Connor and O'Haire, 1988).

The upper part of the glacier has been studied in detail by N. F. Humphrey and his team (e.g. Harper and Humphrey, 1995; Echelmeyer and others, 1996). Towards the terminus, the glacier divides into two tongues where it crosses a large bedrock knoll. This study was carried out on the southern tongue. The southern side of this tongue is composed of a series of Neoglacial moraines and modern-day ice-cored moraines (Fig. lc). The latter are comprised of supraglacial sediment covering the edge of the glacier derived from both the adjacent valley sides and the Neoglacial moraines. However, on the northern side of this tongue there is limited supraglacial source material, and so the surface of the ice is clear. The debris-rich basal ice investigated in this study is located along the northern edge of this tongue (Fig. la), and this is discussed and interpreted below.

\section{Large-scale longitudinal compressive deformation of debris-rich basal ice}

Site 1 is located above a bedrock step, and so represents a small local ice margin. The ice here is $6 \mathrm{~m}$ thick and has a $2 \mathrm{~m}$ thick debris-rich basal ice layer which is deformed into a series of very large compressive structures (Fig. 2), in the form of open and isoclinal recumbent folds and normal and reverse faults.

In the west of the section there is a large open anticlinal recumbent fold which becomes more isoclinal towards the margin (east) (Fig. 2). It overlies a basal fault of unknown 


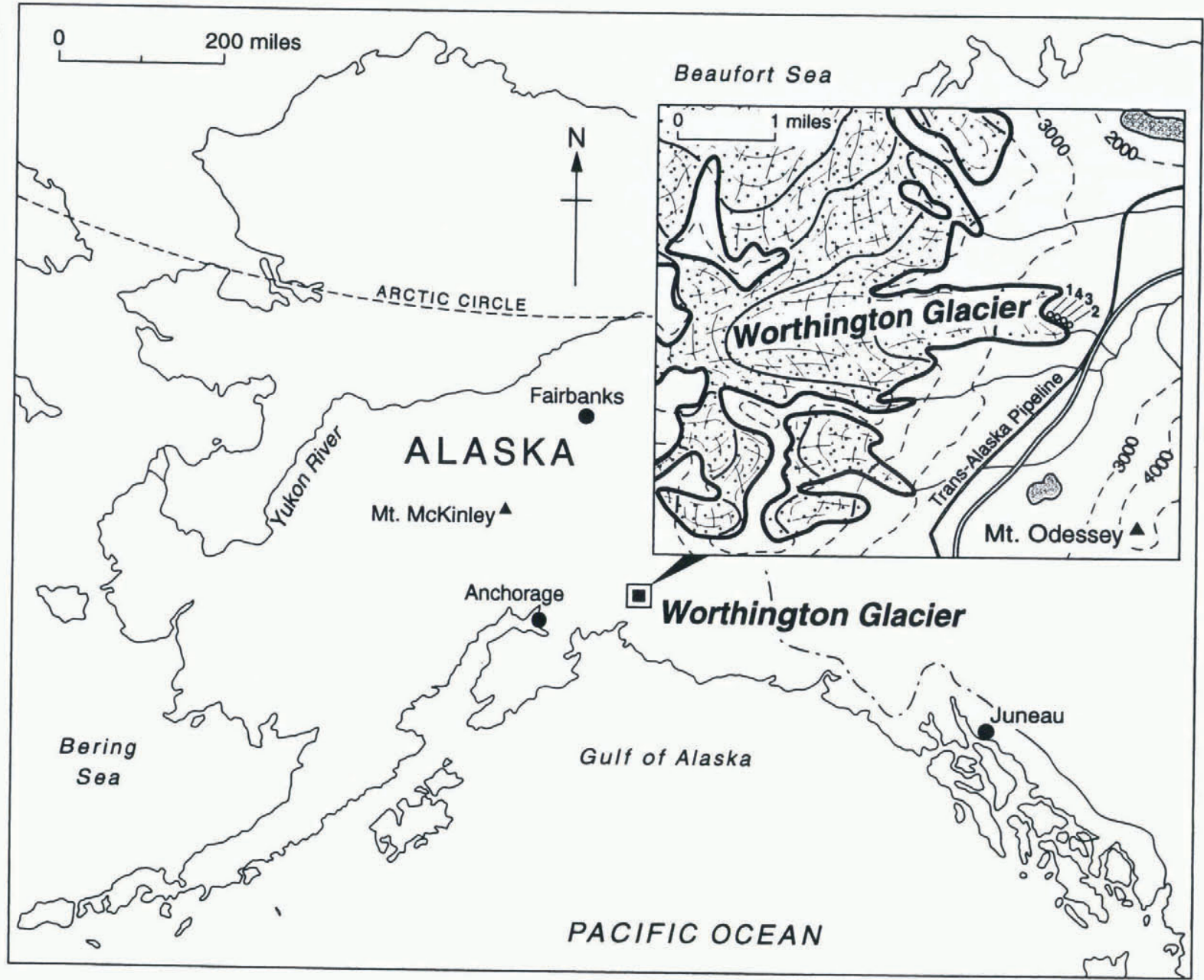

b

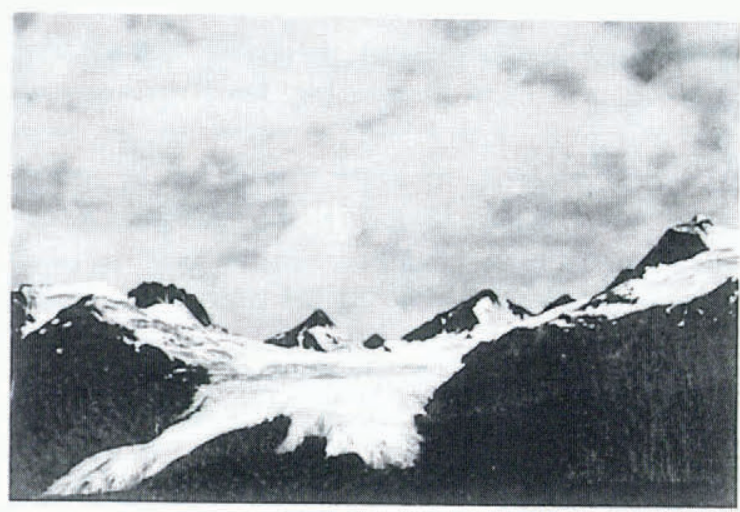

C

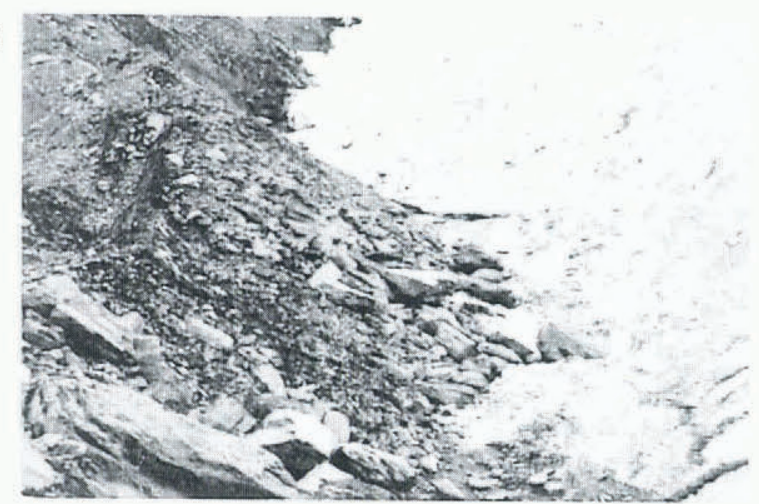

Fig. 1. Worthington Glacier: (a) location and detailed map of the site; (b) photograph of the glacier; (c) photograph of the icecored moraine on the southern side of the southern tongue.

throw (F7). This upper fold overlies a more complex deformed section in the east, containing a "Z" fold, which has been subsequently faulted by a series of at least six subhorizontal faults. This "Z" fold is formed in debris-rich basal ice comprising laminae of frozen debris and bubble-rich ice. It can been seen that where these layers are folded together, the bubble-rich ice layers show internal deformation, whilst the debris-rich layers show more accommodation around the bubble-rich ice and layer thinning. Thus the bubble-rich ice behaved in a more competent manner. Superimposed on these deformation structures are a series of normal faults (F8 and F9) which pass up through the glacier ice.

\section{Interpretation}

This style of deformation formed because of longitudinal compressive stresses in the ice at the margin, followed by simple shear. The presence of the more competent, bubble- rich ice probably caused the ice to fault at this point (F7), leading to the formation of the large open anticlinal recumbent fold (which is probably a nappe) and the lower " $\mathrm{Z}$ " fold, followed by the formation of all the other reverse faults. "Z" folds form in association with a shear zone, that is, a subhorizontal layer with differential vertical deformation rates. Once this "Z" fold had formed, it was faulted into a series of smaller shear zones which moved as individual "mini" shear zones. However, it can be observed that the horizontal faults can be detected in the debris-rich basal ice layer only where they intersect the folds. There may be many other subhorizontal faults in the sequence that are not visible.

Although there is overall shortening of the section caused by the deformation, the large-scale deformation in the debris-rich basal ice layer is not reflected at the debris-richbasal-ice-layer/glacier-ice interface. Therefore continued longitudinal, extensional deformation must have occurred 


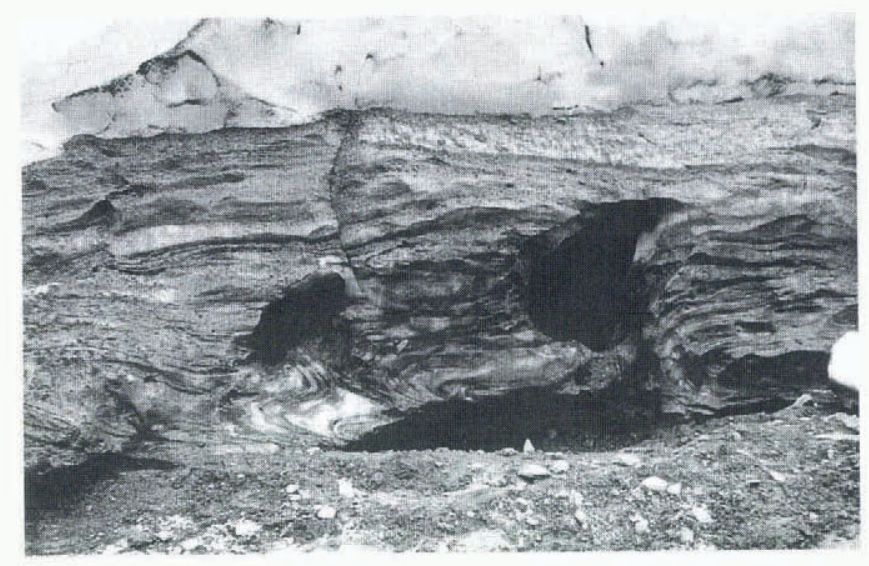

a

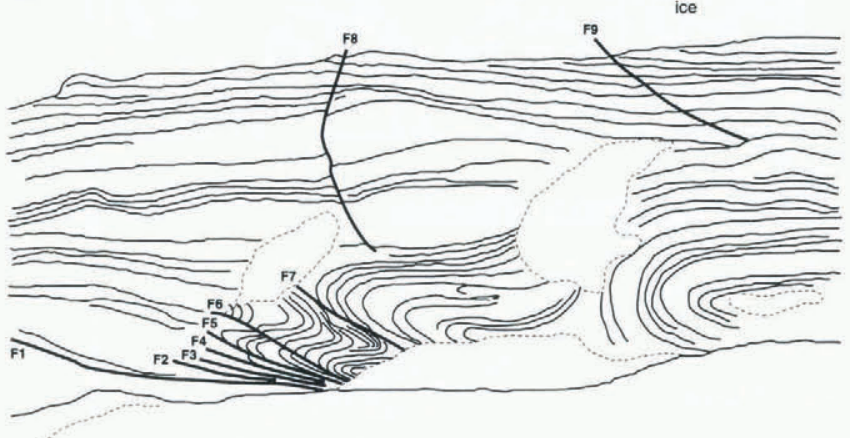

b

Fig. 2. Large-scale deformation at site 1: (a) photograph, (b) interpretation.

in the upper part of the sequence in order to account for the planar nature of the debris-rich-basal-ice-layer/glacier-ice interface. The normal faults (F8 and F9) are superimposed on the sequence, and so are probably associated with the final stage of longitudinal, extensional deformation.

In order to compare the magnitude of this deformation with other sites, we have estimated longitudinal strain by constructing a balanced cross-section (Dahlstrom, 1969). A number of difficulties arose at this site because the debrisrich basal ice layer (i) had undergone ductile deformation, (ii) contained few strain markers, (iii) could have had many more faults than are recorded in Figure 2, and (iv) displays evidence of longitudinal, extensional deformation at the top of the sequence. However, a minimum estimation of the deformation in the lower compressively deformed section was made using the following equation:

$$
e=\frac{\text { Deformed length }- \text { Original length }}{\text { Original length }} \times 100
$$

where $e$ is longitudinal strain. The estimate of minimum longitudinal strain over the given section shown in Figure 2 was $-42 \%$. This illustrates the magnitude of compressive deformation that can occur within the debris-rich basal ice layer.

Longitudinal, compressional deformation is also found associated with proglacial glaciotectonic deformation of sediments (Boulton, 1986; Van der Wateren, 1987; Hart and Boulton, 1991). This can occur either because of simple bulldozing of sediments in front of the glacier or more commonly because of compression in the marginal part of the subglacial deforming wedge (Price, 1970; Sharp, 1984; Hart, 1990). Table 1 shows some examples of the longitudinal compression associated with push moraines reported in the lit-
Table 1. Characteristics of various push moraines

Example

Penckbreen, Svalbard (Hart and Watts, 1997)

Finsterwalderbreen, Svalbard (Hart and Watts, 1997)

Holmströmbreen, Svalbard (Boulton and others, in press)

Eyjabakkajökull, Iceland (Croot, 1988)

Melabakkar-Ásbakkar, west Iceland (Hart, 1994a

Trimingham, East Anglia, U.K. (Hart 1990)

Worthington Glacier, Alaska: debris-rich basal ice layer
$-32$

$-43$

46

$-33$

$-32$

42 erature. It can be seen that the magnitude of longitudinal compressive deformation in the debris-rich basal ice at Worthington is very similar to that within proglacial push moraines.

Additionally, the style of deformation at Worthington is very similar to that at one of the push moraines mentioned in Table 1, Melabakkar-Ásbakkar (structure B), western Iceland (Hart, 1994a) (formed during the Late Weichselian glaciation, 12300-10000 ${ }^{14}$ C years BP; Ingólfsson, 1987). A complex series of earlier folds, reverse faults and nappes, over which was superimposed normal faulting (see Hart, 1994a, fig. 4), were also recorded in this push moraine. Similarly, the top of the structure was marked by a planar boundary, and the sediments along this boundary were in places deformed into tectonic mélange with evidence of boudinage.

This site was interpreted as being initially deformed by longitudinal compression (Fig. 3a-i), and subsequently overridden by the glacier (which destroyed any push moraine landform), which induced subglacial deformation in the upper part of the sequence (Fig. 3a-ii). A similar interpretation is applied at Worthington site 1, that is: (a) the lower compressive structures were formed at the margin of the debris-rich basal ice layer (Fig. 3b-i); followed by (b) longitudinal extension in the upper part of the debris-rich basal ice layer as the glacier continued to move over the site (Fig. 3b-ii).

A number of other workers have reported longitudinal, compressive deformation within the debris-rich basal ice layer at the ice margin (e.g. Hudleston, 1983; Sharp and others, 1994). Furthermore, Hambrey and Huddart (1995) have shown that polythermal glaciers can produce push moraines composed of both debris-rich basal ice and sediment. In addition to this, we have suggested that the style and amount of deformation (and deformational/ice-flow histories) are similar in both the subglacial ice and sediment, which could be taken as further confirmation that similar processes occur in the debris-rich basal ice and deforming layer.

\section{Detailed facies descriptions and interpretations of the debris-rich basal ice}

Site 2 is positioned at the side of the glacier, immediately overlying solid bedrock. Active marginal rivers are currently removing any melt-out products. The debris-rich basal ice layer is $1.2 \mathrm{~m}$ thick (Fig. 4) and comprises three ice beds. Throughout the sequence, debris concentration, grain-size and clast fabrics were taken and the results are shown in Table 2. For the fabric investigations, at each site a minimum of 25 clasts in the ice (and 30 clasts in the diamicton) with an axial ratio greater than $1.5: 1$ were sampled. 


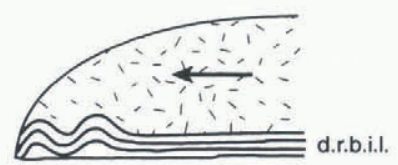

a-ii

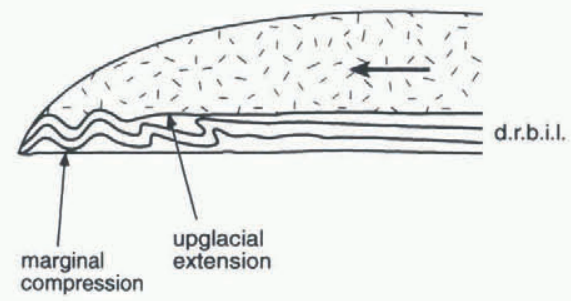

b-i

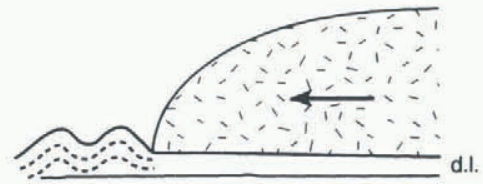

b-ii

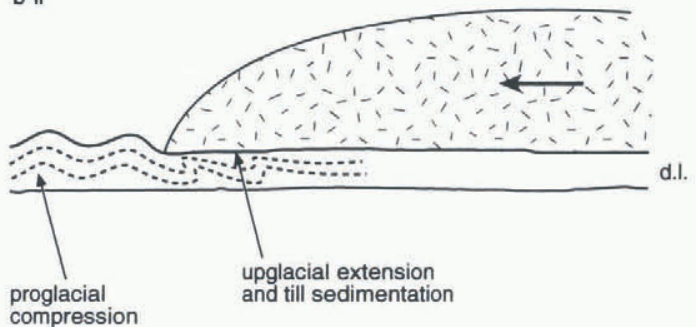

Fig. 3. Comparison of the deformation ( a ) in the debris-rich basal ice at Worthington Glacier and $(b)$ in the deforming layer at Melabakkar-Asbakkar. Stage i, compressive deformation; stage ii, simple shear superimposed on the sites as the glacier advances.

Although 50 clasts are normally accepted as a reliable figure, 25 clasts may accurately depict the orientation maxima (Young, 1969; Stanford and Mickelson, 1985). This particularly applies to the debris-rich basal ice where clasts are rare (and thus sampling difficult) and so the sample closely approximates the population. The initialised eigenvalues were then calculated (Mark, 1973; Dowdeswell and Sharp, 1986) which summarise fabric strength along the three principal directions of clustering.

(a) Zone 1. This consists of a $0.14 \mathrm{~m}$ thick unit of visibly
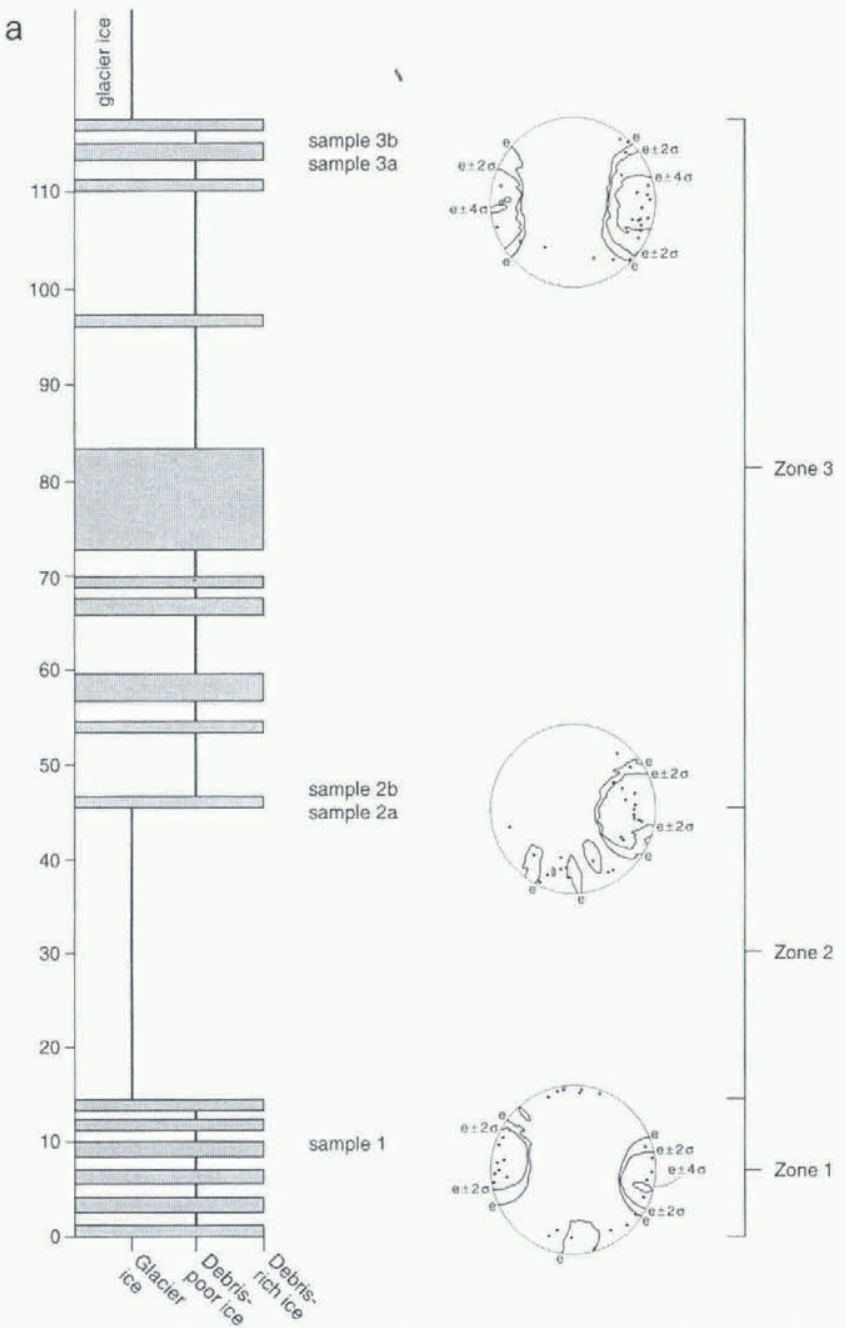

deformed debris-rich basal ice (Fig. 4a and c). Alternating layers of debris-rich and debris-poor ice (which contains a few small debris aggregates) are interspersed with bubblerich ice. This unit shows visible evidence of deformation, including fold noses that are attenuated down-ice, and boudins of debris-poor and bubble-rich ice (which appear to behave in a more competent manner). The upper boundary of this unit is marked by a distinct décollement surface. This unit has a medium-strength fabric, with eigenvalue results of $\mathrm{S} 1=0.591, \mathrm{~S} 3=0.031$.
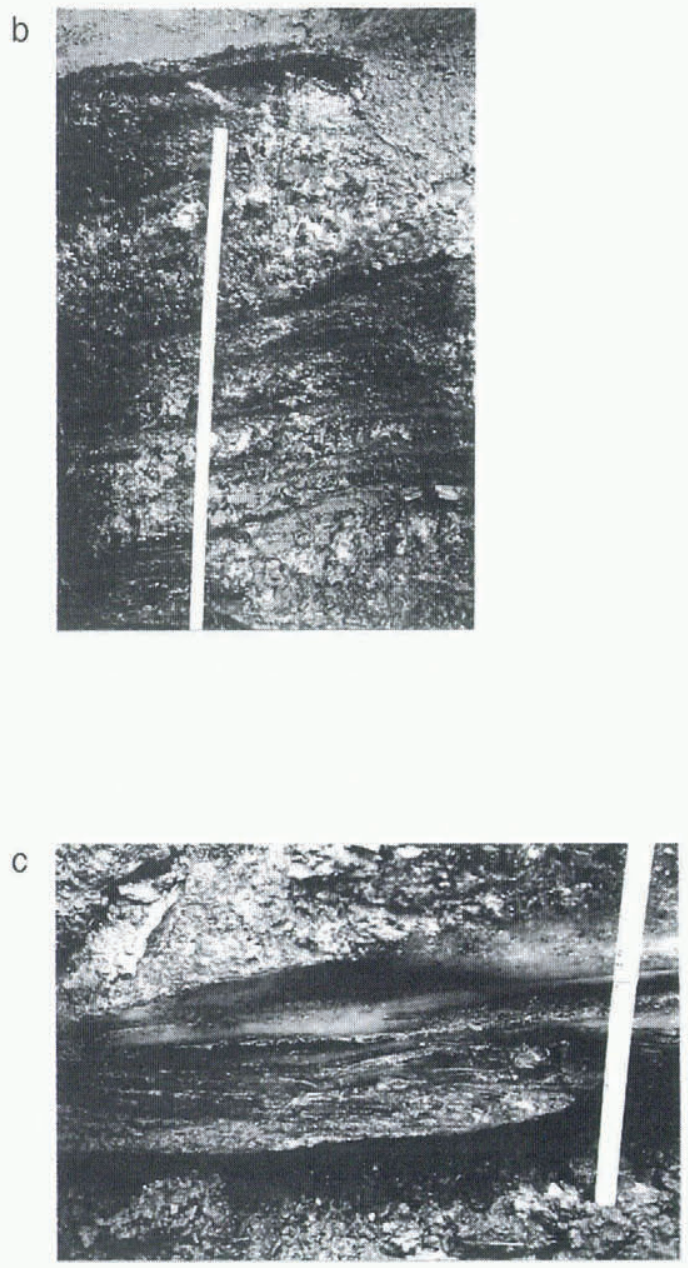

Fig. 4. Site 2: (a) Debris-rich basal ice facies log with fabric details; (b) the stratified solid sub-facies of zone 3; $(c)$ the mélange of zone 1 . 
Table 2. Debris concentrations and ice-fabric results from site 2 (for location see Fig. 6)

\begin{tabular}{llcccc}
\hline Location & Icefacies & $\begin{array}{c}\text { Debrisconc. } \\
\text { \% weight }\end{array}$ & S1 & S3 & Orientation \\
\hline 3a & Debris-rich & - & 0.73 & 0.043 & 89 \\
3b & Debris-poor & 0.003 & - & - & - \\
2a & Debris-rich & 34.34 & 0.552 & 0.052 & 89 \\
2b & Debris-poor & 0.001 & - & - & - \\
1 & Debris-rich & 33.08 & 0.591 & 0.031 & 290 \\
\hline
\end{tabular}

(b) Zone 2. This consists of a $0.31 \mathrm{~m}$ thick unit of bubble-rich ice overlying a décollement surface.

(c) Zone 3. This consists of alternating layers of debris-rich ice and debris-poor ice (Fig. $4 \mathrm{a}$ and b). The debris-rich layers consist of irregular, rounded, medium-density aggregates within an ice matrix; and debris-poor layers contain much fewer aggregates. This style of debris-rich basal ice would be described as stratified solid ice by Lawson (1979).

The debris concentration remains similar throughout the sequence (Table 2). The clast fabric from the basal unit (zone 1) was relatively weak, whilst in the upper unit (zone 3) the fabric was weak at the base of the layer and much stronger at the top.

\section{Interpretation}

The lower unit (zone 1) represents a deformed facies of debris-rich ice, debris-poor ice and bubble-rich ice. The relative amount of deformation in this unit will be discussed below.

The bubble-rich ice in zone 2 was found in a convex (upglacier) bed, which could be traced down from the surface of the glacier. Bubble-rich ice within the debris-rich basal ice layer is relatively common and has been described by a number of researchers (e.g. Knight, 1987). It usually reflects metamorphosed snow, which originally filled crevasses and cavities. In this case it probably (from its shape and position) represents metamorphosed snow that was entrained in crevasses (possibly in the icefall, just up-glacier), and thus incorporated into the debris-rich basal ice layer.

The origin of the upper unit (zone 3 ) consisting of alternating layers of debris-rich and debris-poor ice is more complex. Until recently, this style of debris-rich ice was ascribed to sedimentary processes, normally regelation down-ice of obstacles (e.g. Kamb and LaChapelle, 1969; Lawson, 1979; Hubbard and Sharp, 1995), or subglacial freezing-on of meltwater and subglacial sediments to the base of the glacier (e.g. Lawson and Kulla, 1978; Strasser and others, 1996). In contrast, Hart (1995a) suggested that laminations form, from the deformation of frozen debris, glacier ice and bubble-rich ice. As a result of the different competencies of these materials, any perturbation to flow, especially at the top of this layer, leads initially to folding and then to attenuation of these folds to form tectonic laminations.

At some sites, the tectonic origin of laminations can be clearly established because stratified solid sub-facies ice can be observed to be attenuated to form stratified discontinuous sub-facies ice (e.g. Russell Glacier, Greenland; see Knight, 1997, fig. 8, and interpretations by Waller, 1997). At other sites, the sedimentary origin of laminations can be verified associated with regelation down-ice of bedrock obstacles (e.g. Kamb and LaChapelle, 1964).

The stratified solid sub-facies at this site has no definitive evidence to support either origin. However, there is clear evidence for deformation at this site, in the form of the "mélange" of debris-rich ice, debris-poor ice and bubble-rich ice in zone 1 , and the larger-scale incorporation of a bed of bubble-rich ice (zone 2). We would argue that the subglacial environment is very dynamic (Hudleston, 1983), and once sediment is frozen into the glacier, it must necessarily undergo deformation as the glacier flows. The initial freezing-in process of the debris in zone 3 is unknown, because of subsequent deformation. Deformation is an active, ubiquitous process that occurs at the base of the glacier, constantly influencing the appearance, composition and rheology of the debris-rich basal ice layer (Fig. 5).

The visibly deformed zone 1 is very distinct from the rest of the debris-rich basal ice layer. We suggest this forms because metamorphosed snow is entrained into the base of the sequence, and subsequently intercalated with debris that is recently frozen-on to the glacier base (in a similar fashion to deformation within the stratified solid sub-facies at Russell Glacier; Knight and others, 1994). This produces a mélange because of the relative strength of the bubble-rich ice. Over time, zones 1 and 2 will be mixed together, and the upper part of these two beds will become attenuated to form the laminations similar to those which make up zone 3.

\section{Subglacial sediments and landforms}

At some locations, there is a thin layer of saturated diamicton between the debris-rich basal ice layer and the bedrock. Two examples are discussed from sites 3 and 4 .

(a) Site 3. The ice at this site is $6 \mathrm{~m}$ thick, and contains a firnfilled crevasse, the base of which is incorporated into the debris-rich basal ice layer. The debris-rich basal ice layer at this site is $2 \mathrm{~m}$ thick. However, between the debris-rich basal ice layer and the bedrock there is a $0.1 \mathrm{~m}$ layer of saturated diamicton (with an average grain-size of $0.65 \mathrm{~mm}$ (coarse sand)). This saturated diamicton is observed to exude out from beneath the debris-rich basal ice to form a small $(0.2 \mathrm{~m}$ high $)$ moraine.

(b) Site 4. This is positioned on a rock step and occupies the proglacial area up to $3 \mathrm{~m}$ from the glacier snout. At the glacier margin a small moraine has formed $(0.35 \mathrm{~m}$ high) (Fig. 6). In the proglacial area, there is a series of small arcuate moraines with a distal lineated surface of boulders with lee-side prows and stoss-side grooves (Fig. 7). One such lineation was examined in detail (Fig. 7; see Table 3 for fabric data). This consists of a large clast $(0.22 \mathrm{~m} \times 0.17 \mathrm{~m} \times 0.16 \mathrm{~m})$ with a $0.6 \mathrm{~m}$ long lee-side prow and a $2 \mathrm{~m}$ long stoss-side groove. Fabric measurements in the mound show a relatively low fabric strength, where flow is either aligned with the ice flow (approx. $95^{\circ}$ ) or divergent. A fabric taken $0.15 \mathrm{~m}$ beneath the groove indicates a relatively low fabric strength, whilst two fabrics taken on the surface of the groove (d inside and e outside) indicate fabrics aligned with ice-flow direction.

\section{Interpretation of sites 3 and 4}

We suggest that the thin layer of saturated diamicton is partly formed from the basal melting of the debris-rich ice during the summer. Since the glacier has little supraglacial 


\section{a Initial incorporation process}
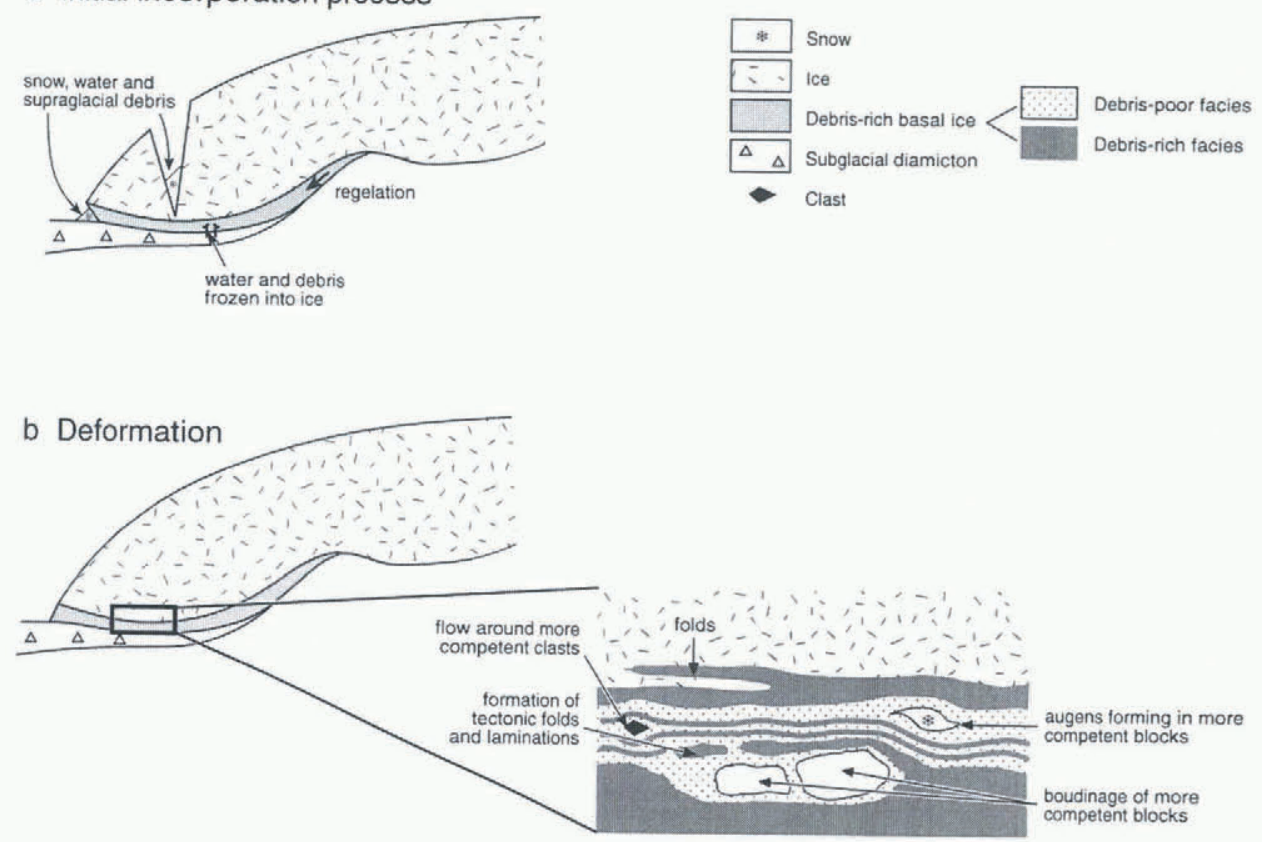

Fig. 5. Schematic diagram to show (a) initial incorporation processes for snow, water and debris into the debris-rich basal ice layer; ( b ) deformation of materials once they are in the debris-rich basal ice layer.

debris on this side of the glacier, and since the saturated material was being extruded from beneath the glacier, it is concluded that the small moraines must represent "squeeze" push moraines (Price, 1970; Sharp, 1984; Hart, 1995b).

We would argue that the large clast from site 4 has been "ploughed" into the sediment as described by Brown and others (1987) and Clark and Hansel (1989). They suggested that large clasts held within the ice are dragged through saturated subglacial sediment, causing the diamicton to be ploughed up on the lee side of the clast, and a groove to form on the stoss side. Ploughing is considered to be an intermediate condition between simple lodgement and full-scale subglacial deformation (Hart and Boulton, 1991). Hart (1995b) has described similar lineations from the foreland of VestariHagafellsjökull, Langajökull ice cap, central Iceland, and has argued that they represent the lowest evolutionary stage in subglacial landforms, associated with relatively low strains and a thin deforming layer. In addition, the till fabric results taken both within the diamicton and in the prow have medium strength, typical of deforming bed till (Benn, 1994, 1995; Hart, 1994b).

The evidence of the "squeeze" push moraines, ploughing and low fabric strength is indicative that the sediment be-

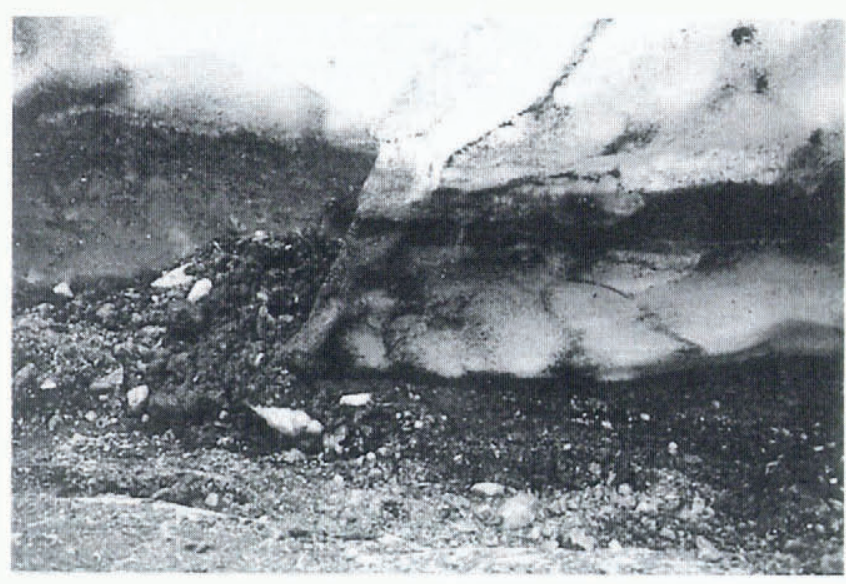

Fig. 6. The small push moraine at site 4.
Table 3. Till fabric data from site 4

\begin{tabular}{lcrrr} 
Sample & $S 1$ & $S 3$ & 0 & $\begin{array}{c}\text { Variation from groove direction } \\
\left(95^{\circ} / 275^{\circ}\right)\end{array}$ \\
\hline a & 0.509 & 0.105 & 284 & 9 \\
b & 0.529 & 0.096 & 294 & 19 \\
c & 0.616 & 0.096 & 121 & 26 \\
\hline
\end{tabular}

neath the glacier is saturated and mobile. Deformation is not high enough to produce flutes, but is sufficient to produce small-scale squeeze push moraines and prow and groove structures. Thus it can be argued that at Worthington Glacier there is a thin (possibly local) mobile bed, which is probably only seasonal. However, we do not yet know the extent of the mobile bed or its effect on glacier motion.

\section{DISCUSSION}

The incorporation, transport and removal of debris from the ice is an important problem in glacial geomorphology. This study has demonstrated the presence of a mobile layer beneath the debris-rich basal ice layer in the lower part of Worthington Glacier. Although the extent of neither layer is known, we can suggest that the debris-rich basal ice layer is fairly extensive since its presence was recorded beneath the upper part of the glacier by Harper and Humphrey (1995). This saturated layer is relatively thin and inactive because Worthington Glacier is a rigid-bed glacier, but was still able to produce small-scale landforms. Therefore this bed can be described as a deforming bed, because although it is not as thick or active as an example from beneath a softbed glacier in a lowland environment (e.g. Breidamerkurjökull, Iceland (Boulton, 1979), or Vestari-Hagafellsjökull (Hart 1995b)), it can be conceptualised as a rigid-bed equivalent.

We suggest that the debris-rich basal ice layer and the 
a

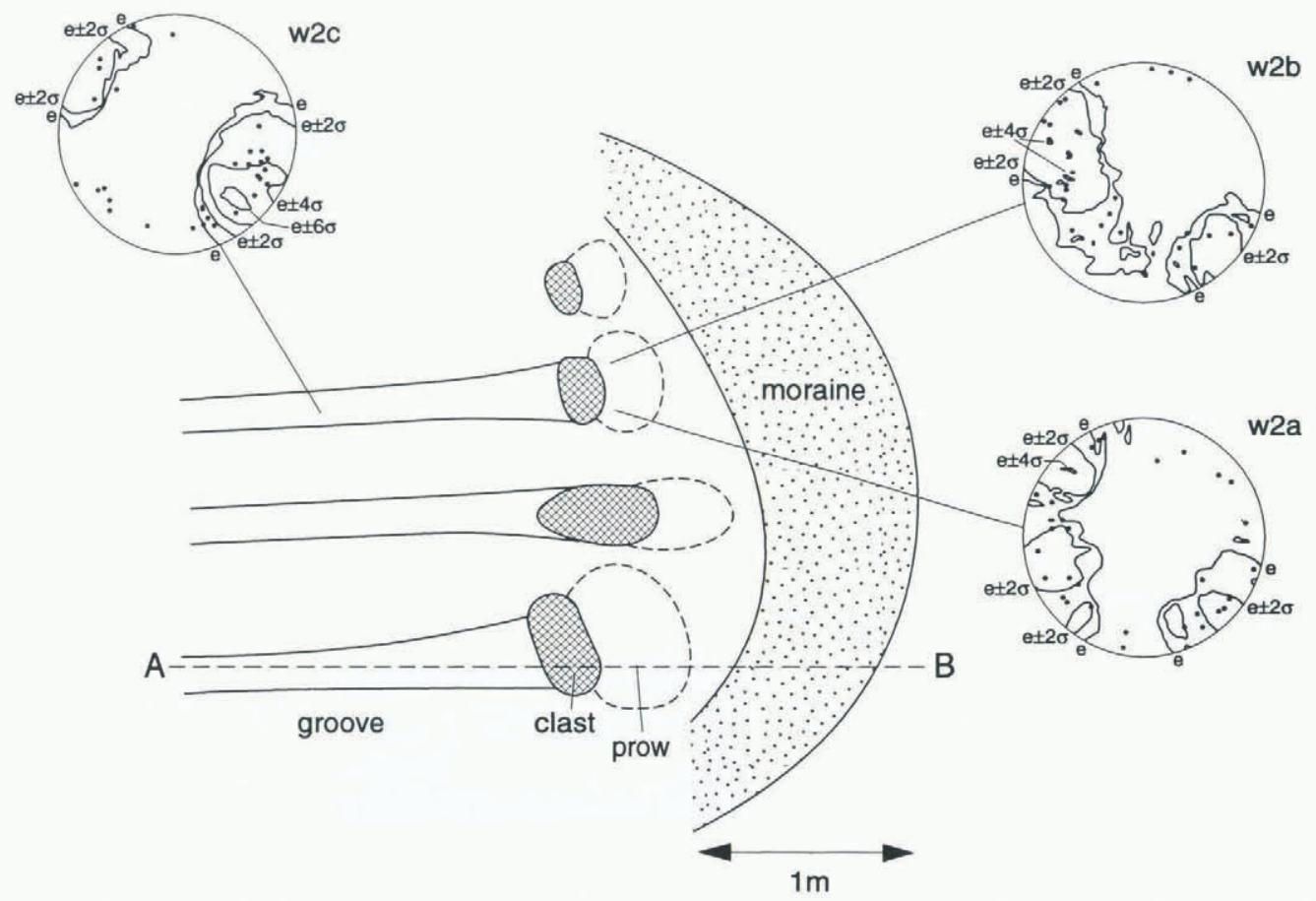

b

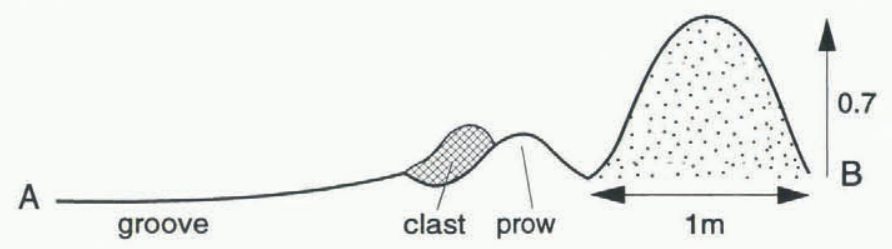

C

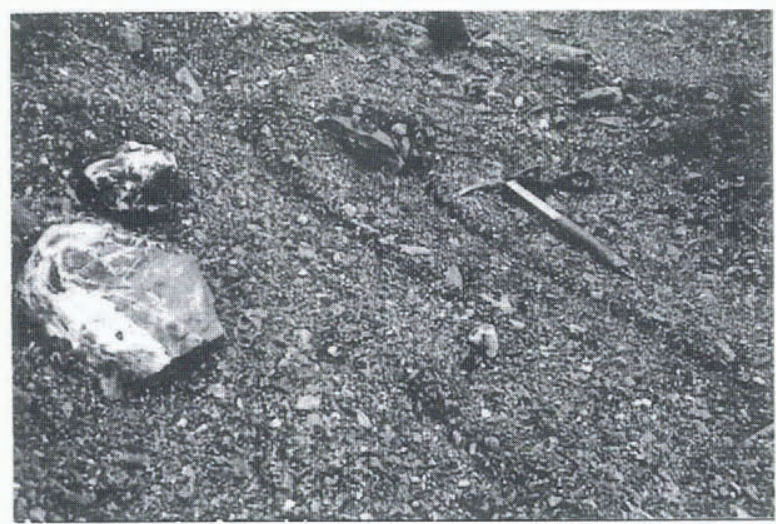

d

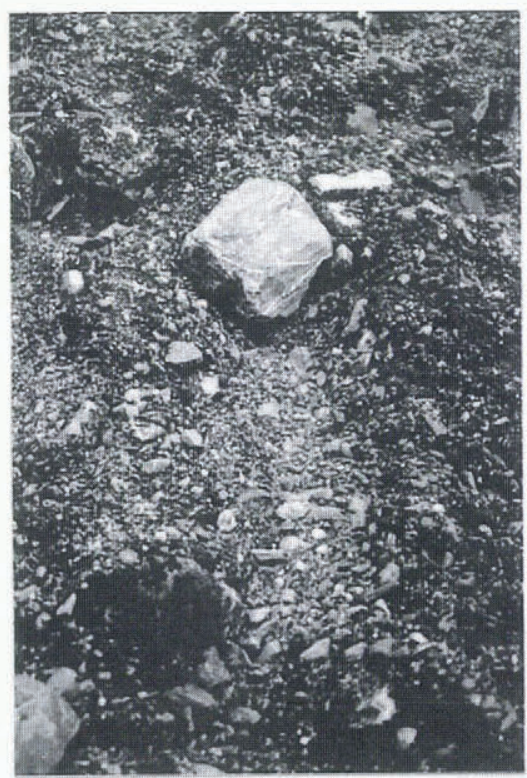

Fig. 7. Detail of the glacial foreland at site 4: (a) schematic diagram to show the plan view of the push moraine and plough and groove structures; ( $b$ ) schematic cross-section through the push moraine and plough and groove structures taken along a transect $A B$, shown in $(a) ;(c, d)$ the plough and groove structures.

deforming layer are dynamically interlinked as follows (schematically illustrated in Figure 8):

Incorporation into debris-rich basal ice layer, and removal of sediment from deforming layer

Sediment can be incorporated into the debris-rich basal ice layer by: (i) local pressure-melting regelation (Weertman, 1957, 1964); (ii) regelation down into unconsolidated sedi- ments (Iverson and Semmens, 1995); (iii) adfreezing due to the oscillation of the freezing front in and out of saturated sediment (Weertman, 1961); (iv) shearing in of debris (Goldthwait, 1951; Echelmeyer and Zhongxiang 1987; Tison and others, 1993); or (v) overriding and apron entrainment in polar and surge-type glaciers (Shaw, 1977; Evans, 1989; Sharp and others, 1994). At Worthington Glacier we cannot comment on the subglacial processes involved in the initial 


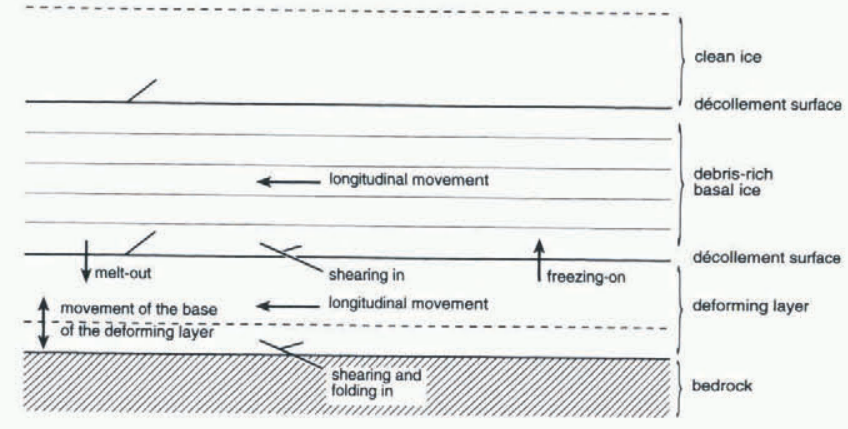

Fig. 8. Schematic diagram of how the debris-rich basal ice layer and deforming layer have similar incorporation, transport and depositional processes.

entrainment of debris into the basal ice layer. Shearing, regelation and net basal adfreezing may all occur. However, once material is incorporated into the basal ice we suggest that it becomes progressively attenuated as the glacier moves down-valley. Close to the margin, it is likely that either the whole or part of the deforming layer (if present) is incorporated back into the basal ice layer during the winter months (hence the similar fabrics in the two layers). Relatively competent bubble-rich ice is also incorporated into the basal ice layer, a process observed at Worthington Glacier through the overriding of ice blocks and the incorporation of firn-filled crevasses and faults.

\section{Transportation in debris-rich basal ice layer and deforming layer}

Once the sediment is incorporated into the debris-rich basal ice layer and deforming layer, it can be transported along and deformed in a zone of high longitudinal extension. At Worthington Glacier almost all of the subglacial sediment transport takes place though the debris-rich basal ice layer, but this is probably the end-member of the debris-rich-basalice-layer/deforming-bed transport continuum, because most of this glacier rests on a hard-rock bed.

\section{Removal of sediment from debris-rich basal ice layer, and incorpora- tion of sediment into deforming layer}

It was suggested earlier that at Worthington Glacier as the base of the debris-rich basal ice layer melts, sediment is incorporated into the deforming layer. This represents a field example of the theoretical ideas of Hart and Boulton (1991), who suggested that melt-out from overlying ice was one of the debris sources for the deforming layer. The other two are advection from up-glacier and shearing-in and/or changes in the thickness of the deforming layer. From the investigation of sediment concentration in the debris-rich basal ice layer, it can be estimated that at Worthington Glacier the melting of $1 \mathrm{~m}$ of debris-rich basal ice layer would produce a $0.07 \mathrm{~m}$ thick deforming layer.

\section{Sediment deposition}

Most sediment that was deposited at Worthington Glacier appears to have been melted out from the debris-rich basal ice layer and then deformed in a subglacial mobile layer before finally coming to rest. Probably, the large clasts were directly deposited from the debris-rich basal ice layer. Thus, although the debris-rich basal ice layer was the dominant transport process at Worthington Glacier, the deforming bed was the dominant depositional source. This site provides further evidence that although similar processes occur in the debris-rich basal ice layer and the deforming layer, only the latter is preserved in the geological record.

\section{CONCLUSION}

This study has shown that longitudinal compressional deformation takes place at the margin of the debris-rich basal ice layer and produces structures and strains similar to proglacial (sediment) glaciotectonic deformation. The deformation seen at Worthington was strikingly similar to that described from a Pleistocene sediment example from Melabakkar-Ásbakkar, with longitudinal compressional deformation at the base of the sequence and then longitudinal extensional deformation at the top, as the glacier continued to override the sequence.

Although the original freezing-in process of the debris into the debris-rich basal layer cannot be established, there is sufficient evidence to show that deformational processes were dominant in the formation of the debris-rich basal ice facies present at Worthington. It was also shown that deformation styles can depend on the relative competency of the different components of the debris-rich basal ice layer. Bubble-rich ice was the most competent material, and once incorporated into the basal ice, perturbed the typical subhorizontal lamination and led to the production of a mélange in association with the simple shear, and faulting associated with the longitudinal compressional deformation.

At this glacier, it appears that there is an interaction between the debris-rich basal ice and the deforming layer, with material being transferred between the layers. In addition, it was suggested that most of the subglacial sediment was transported in the debris-rich basal ice layer, but deposition took place via a mobile saturated layer.

This study has shown that even in a rigid-bed valleyglacier environment, subglacial deformation is an intrinsic part of the debris-rich basal ice layer and the underlying sediment layer. We suggest that this site has provided a rigidbed example of the debris-rich-basal-ice-layer/deforming continuum, and shows that the boundary between the two layers is not fixed but plays an important part in glacial sediment fluxes.

\section{ACKNOWLEDGEMENTS}

We are grateful to R. Watts and K. Martinez for field assistance, to K. Martinez also for photography and to all the other members of the University of Southampton Alaska 1995 Expedition and P. Calkin for information about the site. We would also like to thank T. Aspden and his colleagues in the Cartographic Unit, Department of Geography, for their excellent figure reproduction, and A. Jones for her kind editing advice. This research was funded by U.K. Natural Environment Research Council grant No. GR9/991.

\section{REFERENCES}

Alley, R. B., D. D. Blankenship, C. R. Bentley and S. T. Roonev. 1986. Deformation of till beneath Ice Stream B, West Antarctica. Nature, 322 6074), $57-59$.

Benn, D. I. 1994. Fluted moraine formation and till genesis below a temperate valley glacier: Slettmarkbreen, Jotunheimen, southern Norway. Sedimentolog), 41 (2), 279-292.

Benn, D. I. 1995. Fabric signature of subglacial till deformation, Breidamerkurjökull, Iceland. Sedimentolog), 42 (5), 735-747. 
Boulton, G. S. 1979. Processes of glacier erosion on different substrata. J. Glaciol., 23 (89), 15-38.

Boulton, G. S. 1986. Push-moraines and glacier-contact fans in marine and terrestrial environments. Sedimentology, 33 5), 677-698.

Boulton, G. S. and R. C.A. Hindmarsh. 1987. Sediment deformation beneath glaciers: rheology and geological consequences. 7. Geophys. Res., 92 (B9), $9059-9082$.

Boulton, G. S. and A. S. Jones. 1979. Stability of temperate ice caps and ice sheets resting on beds of deformable sediment. f. Glaciol., 24 (90), 29-43.

Boulton, G. S., J. J. M. van der Meer, J. K. Hart, D. J. Beets, G. H. J. Ruegg and F. M. van der Wateren. In press. The sedimentary and structural evolution of a recent push moraine complex - Holmstrombreen, Spitsbergen. Quat. Sci. Rev.

Brown, N. E., B. Hallet and D. B. Booth. 1987. Rapid soft bed sliding of the Puget glacial lobe. 7. Geophys. Res., 92 (B9), 8985-8997.

Brugman, M. M. and A. Iken. 1988. Studies on the basal-ice zone of Findelen Glacier, Switzerland. [Abstract.] Ann. Glaciol., 10, 200-201.

Clark, P. U. and A. K. Hansel. 1989. Clast ploughing, lodgement and glacier sliding over a soft glacier bed. Boreas, 18 (3), 201-207.

Connor, C. and D. O'Haire. 1988. Roadside geology of Alaska. Missoula, MT, Mountain Press Publishing Co.

Croot, D. G. 1988. Morphological, structural and mechanical analysis of neoglacial ice-pushed ridges in Iceland. In Croot, D. G., ed. Glaciotectonics: forms and processes. Rotterdam, A.A. Balkema, $33-47$.

Dahlstrom, C. D. A. 1969. Balanced cross sections. Can. J. Earth Sci., 6(4), $743-757$.

Dowdeswell, J. A. and M. J. Sharp. 1986. Characterization of pebble fabrics in modern terrestrial glacigenic sediments. Sedimentology, 33(5), 699-710.

Echelmeyer, K. and W. Zhongxiang. 1987. Direct observation of basal sliding and deformation of basal drift at sub-freezing temperatures. $f$. Glaciol., 33 (113), 83-98.

Echelmeyer, K. A. and 8 others. 1996. Airborne surface profiling of glaciers: a case-study in Alaska. J. Glaciol., 42 (142), 538-547.

Evans, D. J. A. 1989. Apron entrainment at the margins of sub-polar glaciers, north-west Ellesmere Island, Canadian High Arctic. J. Glaciol., 35(121), 317-324.

Ferguson, S. A. 1992. Glaciers of North America: a field guide. Golden, CO, Fulcrum.

Goldthwait, R. P. 1951. Development of end moraines in east-central Baffin Island. 7. Geol., 59 (6), 567-577.

Hambrey, M. J. and D. Huddart. 1995. Englacial and proglacial glaciotectonic processes at the snout of a thermally complex glacier in Svalbard. 7. Quat. Sci., 10 (4), 313-326.

Harper, J.T. and N. F. Humphrey. 1995. Borehole video analysis of a temperate glacier's englacial and subglacial structure: implications for glacier flow models. Geology, 23 (10), 901-904.

Hart, J. K. 1990. Proglacial glaciotectonic deformation and the origin of the Cromer Ridge push moraine complex, north Norfolk, England. Boreas, 19 (2), 165-180.

Hart, J. K. 1994a. Proglacial glaciotectonic deformation at MelabakkarAsbakkar, west Iceland. Boreas, 23 (2), 112-121.

Hart, J. K. 1994b. Till fabric associated with deformable beds. Earth Surf. Processes Landforms, 19 (1), 15-32.

Hart, J. K. 1995a. An investigation of the deforming layer/debris-rich basal ice continuum, illustrated from three Alaskan glaciers. \%. Glaciol., $41(139), 619-633$.

Hart, J. K. 1995b. Recent drumlins, flutes and lineations at Vestari-Hagafellsjökull, Iceland. f. Glaciol., 41 (139), 596-606.

Hart, J. K. and G. S. Boulton. 1991. The interrelation of glaciotectonic and glaciodepositional processes within the glacial environment. Quat. Sci. Rev., 10(4), 335-350.
Hart, J. K. and R. Watts. 1997. A comparison of the styles of deformation associated with two recent push moraines, south Van Keulenfjorden, Svalbard. Earth Surf. Processes Landforms, 22, 1089-1107.

Hubbard, B. and M. Sharp. 1995. Basal ice facies and their formation in the western Alps. Arc. Alp. Res., 27 (4), 301-310.

Hudleston, P.J. 1983. Strain patterns in an ice cap and implications for strain variations in shear zones. 7. Struct. Geol., 5 (3-4), 455-463.

Ingólfsson, Ó. 1987. The Late Weichselian glacial geology of the MelabakkarÁsbakkar coastal cliffs, Borgarfjördur, West Iceland. Jökull, 37, 57-80.

Iverson, N. R. and D. J. Semmens. 1995. Intrusion of ice into porous media by regelation: a mechanism of sediment entrainment by glaciers. f. Geophys. Res., 100 (B7), 10,219-10,230.

Kamb, B. and E. LaChapelle. 1964. Direct observation of the mechanism of glacier sliding over bedrock. f. Glaciol., 5(38), 159-172.

Knight, P. G. 1987. Observations at the edge of the Greenland ice sheet: boundary condition implications for modellers. International Association of Hydrological Sciences Publication 170 (Symposium at Vancouver 1987 The Physical Basis of Ice Sheel Modelling), 359-366.

Knight, P. G. 1997. The basal ice layer of glaciers and ice sheets. Quat. Sci. Rev., 16 9), 975-993.

Knight, P. G., D. E. Sugden and C. D. Minty. 1994. Ice flow around large obstacles as indicated by basal ice exposed at the margin of the Greenland ice sheet. 7. Glaciol., 40 (135), $359-367$.

Lawson, D. E. 1979. A sedimentological analysis of the western terminus region of the Matanuska Glacier, Alaska. CRREL Rep.79-9.

Lawson, D. E. and J. B. Kulla. 1978. An oxygen isotope investigation of the origin of the basal zone of the Matanuska Glacier, Alaska. J. Geol., 86 (6), $673-685$.

Mark, D. M. 1973. Analysis of axial orientation data, including till fabrics. Geol. Soc. Am. Bull., 84 (4), 1369-1373.

Price, R. J. 1970. Moraines at Fjallsjökull, Iceland. Arct. Alp. Res., 2(1), 27-42.

Sharp, M. 1984. Annual moraine ridges at Skálafellsjökull, south-east Iceland. f. Glaciol., 30 (104), 82-93.

Sharp, M., J. Jouzel, B. Hubbard and W. Lawson. 1994. The character, structure and origin of the basal ice layer of a surge-type glacier. F. Glaciol., 40 (135), 327-340.

Shaw, J. 1977. Tills deposited in arid polar environments. Can. 7. Earth Sci., 14(6), 1239-1245.

Stanford, S. D. and D. M. Mickelson. 1985. Till fabric and deformational structures in drumlins near Waukesha, Wisconsin, U.S.A. 7. Glaciol., $31(109), 220-228$.

Strasser, J. C., D. E. Lawson, G. J. Larson, E. B. Evenson and R. B. Alley. 1996. Preliminary results of tritium analyses in basal ice, Matanuska Glacier, Alaska, U.S.A.: evidence for subglacial ice accretion. Ann. Glaciol., 22, 126-133.

Tison, J.-L., J.-R. Petit, J.-M. Barnola and W. C. Mahaney. 1993. Debris entrainment at the ice-bedrock interface in sub-freezing temperature conditions (Terre Adélie, Antarctica). J. Glaciol., 39(132), 303-315.

Van der Wateren, D. 1987. Structural geology and sedimentology of the Dammer Berge push moraine, FRG. In Van der Meer, J.J. M., ed. Tills and glaciotectonics. Rotterdam and Boston, A.A. Balkema, 157-182.

Waller, R. I. 1997. The role of tectonism in the distribution, appearance and dynamic behaviour of debris-rich basal ice. (Ph.D. thesis, University of Southampton.)

Weertman, J. 1957. On the sliding of glaciers. J. Glaciol., 3 21), 33-38.

Weertman, J. 1961. Mechanism for the formation of inner moraines found near the edge of cold ice caps and ice sheets. F. Glaciol., 3 (30), 965-978.

Weertman, J. 1964. The theory of glacier sliding. J. Glaciol., 5 (39), 287-303.

Young, J. A. T. 1969. Variations in till macrofabric over very short distances. Geol.Soc. Am. Bull., 80, 2343-2352. 